\title{
TOWARDS NEW BOTANICAL PESTICIDES: THE TOXIC EFFECT OF Eremanthus goyazensis (Asteraceae) LEAVES ESSENTIAL OIL AGAINST Brevipalpus phoenicis (Acari: Tenuipalpidae) ${ }^{\#}$
}

\author{
Edson L. L. Baldin*, Efrain S. Souza e José Paulo G. F. Silva \\ Departamento de Produção Vegetal/Defesa Fitossanitária, Universidade Estadual Paulista, Campus de Botucatu, Rua José Barbosa \\ de Barros, 1780, 18610-307 Botucatu - SP, Brasil \\ Daniel P. Pavarini, Norberto P. Lopes e João L. C. Lopes \\ Departamento de Física e Química, Universidade de São Paulo, Campus de Ribeirão Preto, Av. do Café, s/nº 14040-903 Ribeirão \\ Preto - SP, Brasil \\ Gustavo H. B. Souza \\ Escola de Farmácia, Universidade Federal de Ouro Preto, Rua Costa Sena, 171, 35400-000 Ouro Preto - MG, Brasil
}

Recebido em 26/4/12; aceito em 24/8/12; publicado na web em 25/9/12

\begin{abstract}
This work reports the chemical characterization of Eremanthus goyzensis essential oil and its toxic effect over Brevipalpus phoenicis. The essential oil displayed a major composition of sesquiterpenes (61.87\%) including trans-caryophillene (26.81\%) and germacrene-D $(13.31 \%)$. The fumigation test indicated a promising bioactivity over adult $B$. phoenicis individuals at $24 \mathrm{~h}(2.03 \mu \mathrm{L} / \mathrm{L}$ of air) and $48 \mathrm{~h}(1.08 \mu \mathrm{L} / \mathrm{L}$ of air) of exposition. A brief discussion of essential oils composition and their singular role on the toxic effect over B. phoenicis is provided here. Our results may contribute to a new and profitable use of a species of Brazilian flora on agribusiness.
\end{abstract}

Keywords: Asteraceae; red and black flat mite; botanical pesticide.

\section{INTRODUCTION}

To date, the agribusiness pest control has been done most commonly through spraying synthetic acaricides on crop fields. Despite its wide employment, such chemicals are known for their drawbacks e.g., high prices, environmental and health injuries, and their capabilities of inducing Acari resistance. ${ }^{1}$

Brevipalpus phoenicis (Geijskes, 1939) (Acari: Tenuipalpidae) is a cosmopolitan false-spider-mite which has various plants as hosts. ${ }^{2,3}$ Under Brazilian geoclimate conditions the specie plays a pivotal role of the transmission of citrus leprosis virus (CiLV), a RNA virus responsible for citrus leprosies, mainly on sweet orange trees. ${ }^{4,5}$ The disease negatively impacts Brazilian citrus agribusiness by an annual estimation of 100 million dollar expense in Brevipalpus spp. control. ${ }^{6}$ Before vanishing from Florida crop fields, the disease had almost shut down the citrus industry in USA. ${ }^{7}$ There are reports that there is a northward movement of the virus, which could endanger citrus crop fields of North America. ${ }^{8}$

Currently B. phoenicis suffers a selective pressure caused by the most commonly used acaricides on citrus crop protection such as dicofol, ${ }^{9,10}$ hexythiazox, ${ }^{11}$ and propargite. ${ }^{12}$ In addition to this pressure, B. phoenicis shows parthenogenetic development leading to a quick promotion of the appearance of an evolved and chemical-resistant type of mite.

Eremanthus goyazensis (Gardner) is an Asteraceae specie endemic of quartzite rupestrian fields. This ecosystem emerges at the top of Brazilian savannas ("Cerrado") located in central Brazil within the states of Minas Gerais, São Paulo, Bahia, and Goiás. ${ }^{13}$ At this habitat the specie is known as "candeia", among some other species of the genus.

The current literature registers for the genus Eremanthus a chemical volatile fraction featured by monoterpenes, such as $\beta$-pinene, $\beta$-mircene and a majority of sesquiterpenes highlighting a-bisabolol,

\footnotetext{
* e-mail: elbaldin@fca.unesp.br

\#Artigo em homenagem ao Prof. Otto R. Gottlieb (31/8/1920-19/6/2011)
}

$\beta$-caryophyllene and germacrene-D. ${ }^{14,15}$ In leaves, $\alpha$-bisabolol is detected in high concentrations. The Eremanthus spp. wood logging takes place at the habitat often and the leaves are dismissed along the process, thus it may be commercially interesting to explore this potential highly valued by-product.

This genus is circumscribed in Lychnophorinae sub-tribe (Vernonieae). The subtribe had its chemistry recently reviewed, ${ }^{16}$ where a variety of sesquiterpenes lactones (SLTs) majority is described. The common phytochemical investigations among Lychnophorinae species from late 1970 ' ${ }^{17-21}$ used to be proceed focusing on the analysis of the medium polarity fractions of leaves extracts, which only afforded non-volatile compounds isolation. Such a goal-oriented phytochemical workflow may explain why the volatile fractions of Lychnophorinea species were somehow dismissed.

Regarding all the damages and risks of the B. phoenicis upon citrus crops as well as the agribusiness needs of novel, safe and efficient ways to control crop pest we investigated toxic effects of E. goyzensis leaves essential oil over B. phoenicis adult individuals. The Eremanthus species were used in order to move forward on the phytochemical characterization of endangered Asteraceae species.

\section{EXPERIMENTAL}

\section{Botanic material}

Aerial parts (leaves) of Eremanthus goyazensis were harvested in the morning during the 2011 summer at the limits of Ouro Preto MG, Brazil. The plant was identified by Dr. G. H. B. de Souza, and a voucher (code number - NPL372) was kept at Herbarium UEC in University of Campinas - Brazil. Harvesting was done under the allowance of CNPq (010143/2011-4).

\section{Essential oil and chemical analysis by GC-MS}

The fresh plant material (690.0 g of E. goyazensis leaves) was placed inside a two liter Florence flask which was connected to a 
Clevenger apparatus modified for hydrodistillation. The entire process elapsed $4 \mathrm{~h}$ of distillation under controlled temperature $\left(100^{\circ} \mathrm{C}\right)$ and the yield was calculated based on the weight of the fresh leaves. In the end, a slight difference between the still water and essential oil densities allowed the separation of 2 distillated layers. The organic layer, formed by essential oil, was collected, dried by allowing its contact with anhydrous $\mathrm{Na}_{2} \mathrm{SO}_{4}$ and maintained under a $\mathrm{N}_{2}$ micro-ambient inside amber vials at $-20^{\circ} \mathrm{C}$. All the storage conditions were kept until the start time of the chromatographic analysis and fumigant effect essays.

\section{Fingerprinting and semi-quantitative measurements by GC-MS}

The previously obtained essential oil was chemically analyzed through a Shimadzu QP2010 GC-MS system. An electron ionization mass spectrometry (EI-MS) detector has operated under a settled 70 $\mathrm{eV}$ ionization energy, source temperature of $250^{\circ} \mathrm{C}$, scanning ratio of $0.50 \mathrm{scan} / \mathrm{s}$ for a method with total ion chromatogram (T.I.C.) analyzer mode switched on, within a mass weight frame corresponding to the interval of 40 up to $500 \mathrm{~m} / \mathrm{z}$ mass charge ratio. Chromatographic resolution was guaranteed by the use of a split injector $\left(240{ }^{\circ} \mathrm{C}\right)$ operating at a ratio of $1 / 10$ injection quantity towards the column. One DB-5MS (30 m x $0.25 \mathrm{~mm}$ x $0.25 \mathrm{um}$ ) column was employed and Helium was used as a carrier gas (flow: $1.33 \mathrm{~mL} / \mathrm{min}$; settled pressure: $81.5 \mathrm{kPa})$. Programmed heating $\left(3^{\circ} \mathrm{C} / \mathrm{min}\right)$ was used to elute the compounds out of the column orderly and clearly. Starting temperature was at $60{ }^{\circ} \mathrm{C}$ and finishing temperature was $240{ }^{\circ} \mathrm{C}$.

The chemical fingerprint was acquired by the GC-MS data processing. The mass spectra for each and every major signal of essential oil's chromatogram was compared, using GC-MS labsolution ${ }^{\circledR}$ software, with the spectra of 3 commercial data Banks (NIST 62, Wiley 7 and FFNSC 1.3). In parallel, the chromatographic relative retention index (R.R.I.) was calculated using data of the injection of a homologous set of $n$-alkanes $\left(\mathrm{C}_{9}-\mathrm{C}_{22}\right)$ on Kováts equation. ${ }^{22}$ Mass spectra similarities values higher than $95 \%$ combined with RRIs values higher than $99 \%$ were considered "perfect match" at the identification process.

For semi-quantitative analysis, the data generated at GC-MS were used by the software in a way to know the peak area by integration of each signal.

\section{B. phoenicis treatments}

All spider mites were maintained in captive breeding system at the lab $\left(\mathrm{T}=25 \pm 1{ }^{\circ} \mathrm{C}\right.$; R.H. $=70 \pm 10 \%$ and daylight period $\left.=12 \mathrm{~h}\right)$. Populations of $B$. phoenicis were allowed to breed on acaricide-free fruits of Citrus sinensis L. Osbeck, var. Pera-rio. Every fruit was harvested, washed, dried and half of their surfaces covered with paraffin, while the other half was bordered with glue (Tanglefoot ${ }^{\circledR}$ ) and left raw in order to hold the spider mite infestations.

A simulation of Citrus scab was made by brushing a mixture of sand, plaster, wheat flour and distilled water (4:1:1:3) over all the fruits' surface right before the placement of the spider mites at the arena, in order to create the physical conditions of the disease in the experiment, which make B. phoenicis colonization favored. ${ }^{6,23,24}$

After the placement of 50 spider mites in each arena, the fruits were kept on a polystyrene plaque in a temperature controlled room settled for the same conditions used in a captive breeding system in the lab. According to the needs observed along the experiment, the fruits were renewed.

\section{Fumigant effect of Eremanthus goyazensis essential oil}

Bioassays were performed in a temperature controlled room settled for the same conditions used in a captive breeding system at the lab, and following a factorial arrangement $6 \times 3$ (factor $1=6$ concentrations of essential oil; factor $2=3$ exposure times). A completely randomized design (CRD) was used and executed in 4 replicates. Spider mites were exposed to the following doses of E. goyazensis leaves essential oil: $0 ; 0.5 ; 1.0 ; 1.5 ; 2.0$ and $2.5 \mu \mathrm{L}$ of oil/ $\mathrm{L}$ of air. The mortality rate was accessed after 24,48 and $72 \mathrm{~h}$ of exposure.

In order to observe the fumigant effect of E. goyazensis leaves essential oil on B. phoenicis mites, $0.5 \mathrm{~L}$ plastic bags adapted to work as fumigation chambers were used. Inside each bag a wad of wet cotton was placed and upon their surfaces were 4 discs of Citrus sinensis peel $(\varnothing=3 \mathrm{~cm}$; one disc $=1$ repetition $)$ containing 10 adults, which totaled 40 spider mites per chamber.

Afterwards, all the different concentrations described previously were reached at the chambers. Tiny pieces $(5 \times 2 \mathrm{~cm})$ of absorbent paper were placed at the boundaries of the chamber. The dosage of the essential oils on the paper surfaces was done with a micropipette (Acura-Socorex ${ }^{\circledR}$ ). The procedure was adapted from literature. ${ }^{25}$ Spider mite colonies after 24,48 and $72 \mathrm{~h}$ of exposure were accessed to evaluate the mortality. Mites were considered dead if after a slight touch of a thin brush on their back they did not move for a distance equal to their body size.

\section{B. phoenicis mortality statistics}

All data from fumigant effect essay were analysed with a one-way analysis of variance (ANOVA); for analysis, the original data (x) were transformed to $(x+0.5)^{1 / 2}$. The means were compared using the Tukey test. ${ }^{26}$ Statistical analysis was performed using the PROC GLIMMIX procedure in the SAS software package. ${ }^{27}$ For lethal doses $\left(\mathrm{LD}_{50}\right)$ measurements, a Probit analysis was done through a 4.3.0 version of Stat Plus software.

\section{RESULTS AND DISCUSSION}

The essential oil hydrodistillated from E. goyazensis leaves displayed a light-green color and the process had a yield of $0.15 \% \mathrm{v} / \mathrm{m}$. A trustful and reliable identification by GC-MS fingerprinting identified a majority of 12 different terpenoids (Figure 1). Hydrocarbons skeletons of sesquiterpenes are $61.87 \%$ of the T.I.C. area and within this group there is a majority of trans-caryophillene $26.81 \%$ (Table 1).

Caryophyllene-like sesquiterpenes are common to occur in many species of Lychnophorinea subtribe (Vernonieae: Asteraceae). The majority of the chemical reports are from phytochemical studies of non-polar extracts that were carried out 40 years ago ${ }^{18-21,28}$ but also from a few recent essential oil chemical investigations exempli gratia: Eremanthus erythropappus. ${ }^{14,15}$ Time-scale shifts of caryophillene levels have been reported, ${ }^{29-31}$ which raises up the importance of knowledge of chemical ecology in the issue of bioprospecting.

$\mathrm{LD}_{50}$ values for E. goyazensis leaves essential oils mortality over B. phoenicis were measured as well as all their confidence intervals (Table 2). The data displayed a high toxicity of the oil over the mite even at the slighter exposition time-frame. The following longer exposure time, $48 \mathrm{~h}$, showed that a higher toxicity decreases the $\mathrm{LD}_{50}$ values down to $1.08 \mu \mathrm{L} / \mathrm{L}$ of air. In sequence, $72 \mathrm{~h}$ of exposure time was toxic enough to kill the entire spider mite population at the lower dose $(0.5 \mu \mathrm{L} / \mathrm{L}$ air $)$ of essential oil that made the $\mathrm{LD}_{50}$ measure not feasible. In general, mortality increased as the exposure period increased (Figure 2).

Combined analysis of mortality, time of exposure and doses showed that at the total time of exposure equal to $24 \mathrm{~h}$, just the highest dose was significantly different $(F=5.42 ; d f=5 ; P<0.05)$ for the control in means of toxicity (Table 3 ). An average of 6.75 individuals' mortality was observed. At the same point of view, $48 \mathrm{~h}$ time 


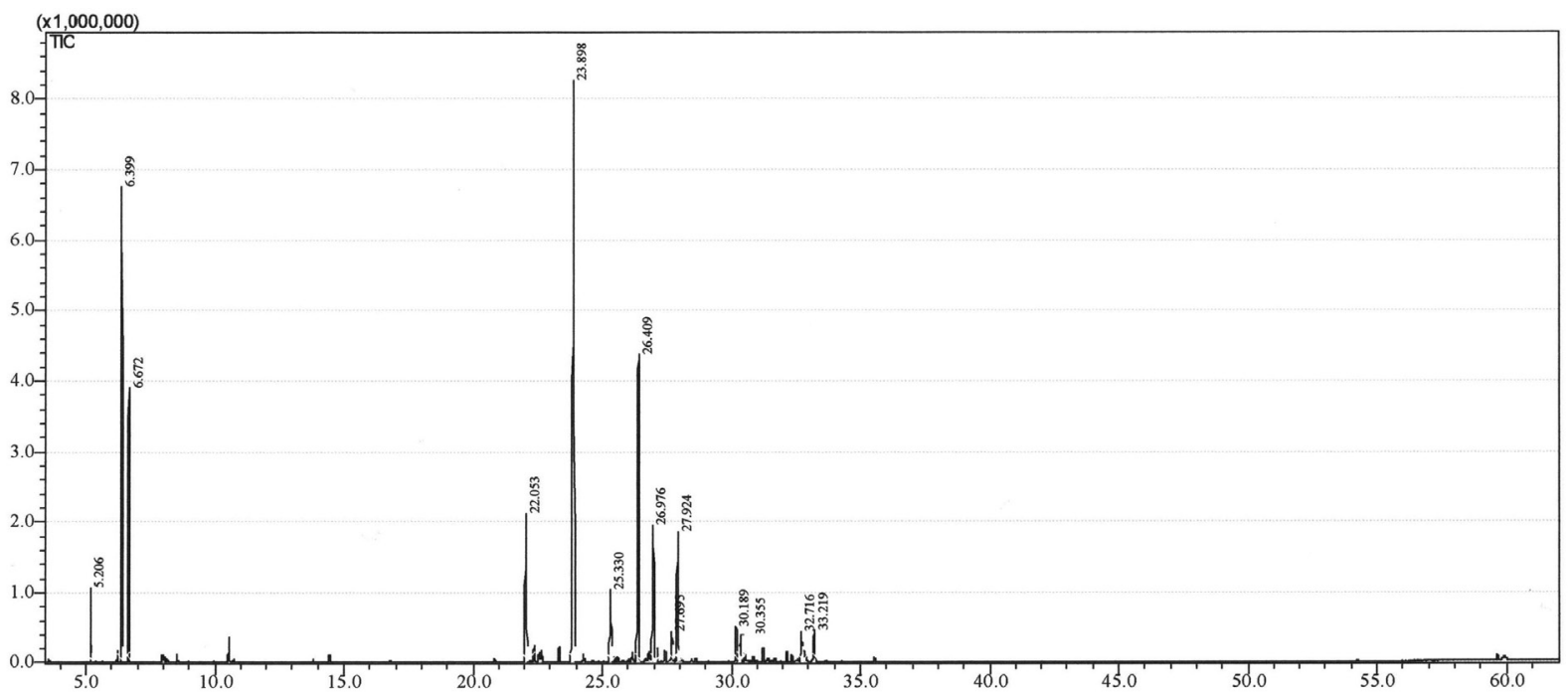

Figure 1. Total ion chromatogram of E. goyazensis leaves essential oil. Acquired in GC-MS QP2010 Shimadzu (70 eV)

Table 1. Relative percentage of Eremanthus goyazensis leaves essential oil compounds

\begin{tabular}{lccc}
\hline Name & R.R.I. & $\mathrm{R}_{\mathrm{t}}$ & $\%$ TIC \\
\hline$\alpha$-pinene & 935 & 5.20 & 1.53 \\
$\beta$-pinene & 985 & 6.40 & 11.34 \\
$\beta$-mircene & 990 & 6.67 & 6.58 \\
$\alpha$-copaene & 1375 & 22.05 & 6.02 \\
trans-cariophyllene & 1425 & 23.98 & 26.81 \\
$\alpha$-humulene & 1450 & 25.33 & 3.05 \\
germacrene D & 1475 & 26.41 & 13.31 \\
Bicyclogermacrene & 1487 & 26.97 & 6.03 \\
$\gamma$-cadinene & 1508 & 27.69 & 1.21 \\
-cadinene & 1514 & 27.92 & 5.44 \\
spathulenol & 1574 & 30.19 & 1.58 \\
cariophyllene oxide & 1577 & 30.35 & 1.15 \\
unknown & 1639 & 32.71 & 1.28 \\
unknown & 1651 & 33.22 & 1.57 \\
Monoterpenes hydrocarbons & - & - & 19.45 \\
Sesquiterpenes hydrocarbons & - & - & 61.87 \\
Oxygenated sesquiterpenes & - & - & 2.73 \\
Identified (\%) & - & - & 84.05 \\
\hline Relive retentindexes & & & \\
\hline
\end{tabular}

Relative retention indexes (R.R.I.) were determined according Kováts equation. Retentions time $\left(\mathrm{R}_{\mathrm{t}}\right)$ were plotted in this table at the same scale displayed in chromatogram. Percentage of total ion chromatogram (\% TIC) represents each single compound's percentage of the sum of all ions recorded at mass spectrometer during the analysis

of exposure showed relevant toxicity $(F=3.74 ; d f=5 ; P<0.05)$ at the highest dose, as well. On the other hand $72 \mathrm{~h}$ time of exposure all doses were significantly $(F=6.84 ; d f=5 ; P<0.05)$ toxic. The interaction between concentrations and exposure times was not significant $(F=4.27 ; d f=10 ; P>0.05)$ in this assay (Table 3$)$, which means that regardless of the tested range of the variable "exposure time", the effects of different doses are similar.

Literature reports a fumigant effect of Xylopia sericea (Annonaceae) leaves essential oil over Tetranychus urticae (Acari: Tetranychidae) at a $\mathrm{LD}_{50}$ of $2.04 \mu \mathrm{L} / \mathrm{L}$ of air, however these essential
Table 2. $\mathrm{LC}_{50}$ mean values of Eremanthus goyazensis leaves essential oil to Brevipalpus phoenicis in fumigant assay

\begin{tabular}{ccccc}
\hline $\begin{array}{c}\text { Exposure } \\
\text { times }\end{array}$ & $\mathrm{n}$ & $\begin{array}{c}\mathrm{LC}_{50} \\
(95 \% \mathrm{CL})^{(1)}\end{array}$ & Slope $\pm \mathrm{SE}$ & $X^{2}$ \\
\hline $24 \mathrm{~h}$ & 40 & $2.03(1.60-2.45)$ & $1.27 \pm 0.48$ & 1.82 \\
$48 \mathrm{~h}$ & 40 & $1.08(0.52-1.64)$ & $1.35 \pm 0.24$ & 2.17 \\
\hline
\end{tabular}

(1) $\mathrm{LC}_{50}$ values are expressed as $\mu \mathrm{L} / \mathrm{L}$ air of pure essential oil with their $95 \%$ confidence limits (CL)

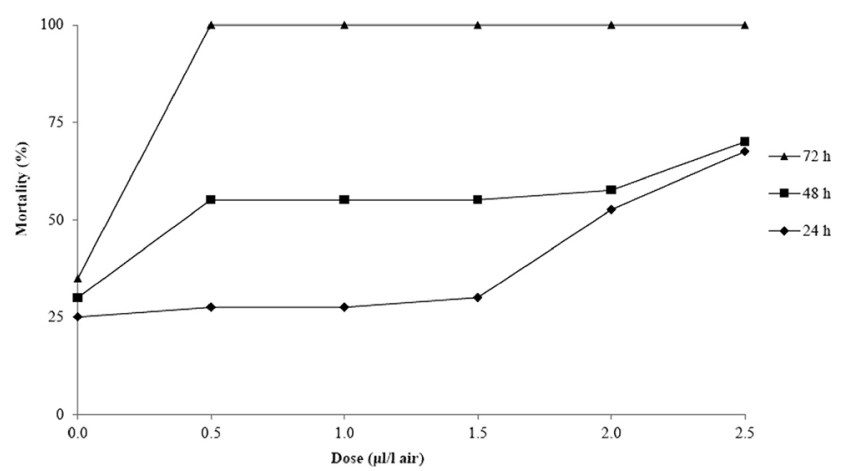

Figure 2. Mortality of B. phoenicis exposed to three periods of time to E. goyazensis leaves essential oil

Table 3. Averages $( \pm \mathrm{SE})$ of mortality of B. phoenicis at 3 different exposure time-frame to E. goyazensis leaves essential oils

\begin{tabular}{cccc}
\hline Concentration $^{(1)}$ & $24 \mathrm{~h}^{(2)}$ & $48 \mathrm{~h}^{(2)}$ & $72 \mathrm{~h}^{(2)}$ \\
\hline 0.0 & $2.50 \pm 0.65 \mathrm{~b} \mathrm{~A}$ & $3.00 \pm 0.41 \mathrm{~b} \mathrm{~A}$ & $3.50 \pm 1.22 \mathrm{~b} \mathrm{~A}$ \\
0.5 & $3.00 \pm 0.71 \mathrm{ab} \mathrm{A}$ & $5.50 \pm 0.96 \mathrm{ab} \mathrm{A}$ & $10.0 \pm 0.00 \mathrm{a} \mathrm{A}$ \\
1.0 & $2.75 \pm 0.63 \mathrm{ab} \mathrm{A}$ & $4.50 \pm 0.96 \mathrm{ab} \mathrm{A}$ & $9.50 \pm 0.29 \mathrm{a} \mathrm{A}$ \\
1.5 & $2.75 \pm 0.25 \mathrm{ab} \mathrm{A}$ & $5.50 \pm 0.87 \mathrm{ab} \mathrm{A}$ & $9.25 \pm 0.48 \mathrm{a} \mathrm{A}$ \\
2.0 & $5.25 \pm 1.44 \mathrm{ab} \mathrm{A}$ & $5.75 \pm 1.65 \mathrm{ab} \mathrm{A}$ & $9.25 \pm 0.25 \mathrm{a} \mathrm{A}$ \\
2.5 & $6.75 \pm 0.63 \mathrm{aA}$ & $7.00 \pm 0.82 \mathrm{a} \mathrm{A}$ & $10.0 \pm 0.00 \mathrm{a} \mathrm{A}$ \\
\hline
\end{tabular}

(1) Concentrations expressed as $\mu \mathrm{L} / \mathrm{L}$ air of pure essential oil. ${ }^{(2)}$ Means followed by the same lower case letter in the column or upper case letter in the row do not differ by Tukey test $(P \geq 0.05) ; \mathrm{CV}-$ coefficient of variation $=21.42 \%$ 
oils are markedly a cubenol $(57.43 \%)$ and $\alpha$-epi-muurolol $(26.09 \%)$ rich essential oil. ${ }^{32}$ Such previous investigation of Cerrados' species toxicity over Acari species does not support the result of this present study, which found a trans-caryophyllene $(23.98 \%)$ rich essential oil of Eremanthus goyzensis (Vernonieae: Asteraceae) leaves that is toxic over Brevipalpus phoenicis. Nevertheless, our recent investigation of Lychnophora ericoides (Vernonieae: Asteraceae) leaves essential oil fumigant effect over the already mentioned Tetranychus urticae has shown that a monoterpenes rich oil has $\mathrm{LD}_{50}$ of $8.01 \mu \mathrm{L} / \mathrm{L}$ of air. ${ }^{33}$

Regardless of one's specific chemical features, e.g., caryophillene discussed above, the fumigant toxic effect of essential oils over Acari species are overall more likely linked to the complex mixture of terpenoids that are frequently found in such oils. A recent report of Piper spp. essential oils toxicity over Rhipicephalus sp. (Acari: Ixodidae) larvae (immersion test; $\mathrm{LC}_{50}$ of $2.33 \mu \mathrm{L} / \mathrm{mL}$ of solution for $P$. mikanianum) showed that those oils with a chemical profile of phenylpropanoids have higher activity compared to those with chemical profile of terpenoids. ${ }^{34}$ On the other hand, Protium bahianum fruits and leaves essential oils are free of phenylpropanoids, have high levels of pinene (34\%) and are toxic to T. urticae. ${ }^{35}$ Noteworthy is the presence of this monoterpene (pinene) in E. goyazensis essential oils composition presented is this current investigation. Other species of the genus Protium such as P. heptaphyllum have been reported $^{36}$ to have a terpene rich essential oil a-terpinene $(47.6 \%)$, 9-epi-caryophillene (21.4\%) and 14-hydroxy-9-epi- caryophillene (16.7\%), that is toxic to T. urticae.

\section{CONCLUSION}

Encouraged by literature data briefly discussed above and based in our data presented herein this study, we might conclude that Eremanthus goyzensis leaves essential oil are very toxic to adult Brevipalpus phoenicis individuals. Field dilutions of the E. goyazensis oils could feature a possible "resistance-free" approach to stop the northward movement of B. phoenicis in order to avoid endangering orange tree fields.

The scenario of Cerrados' devastation and the wood logging of Eremanthus spp. should be an opportunity for this preliminary study to turn this endemic specie into a potential source of a botanical pesticide. Such a new valuation of Eremanthus spp. would be a contribution towards its conservation, as well as another proof of the biome importance on Agrochemicals discovering.

\section{ACKNOWLEDGMENTS}

The authors are grateful to M. A. Weidner (University of Nebraska, Lincoln, USA) for reviewing on the language.

\section{REFERENCES}

1. Perry, A. S.; Yamamoto, I.; Ishaaya, I.; Perry, R.; Insecticides in agriculture and environment - retrospects and prospects, Springer: Berlin, 1998.

2. Trindade, M. L. B.; Chiavegato, L. G.; Laranja 1990, 11, 227.

3. Maia, O. M. A.; Buzzi, Z. J.; Rev. Bras. Zool. 2006, 23, 886.

4. Chiavegato, L. G.; Mischan, M. M.; Silva, M. A.; Científica 1982, 10, 265.

5. Oliveira, C. A. L. In Aspectos ecológicos do Brevipalpus phoenicis; Oliveira, C. A. L.; Donadio, L. C., eds; Funep: Jaboticabal, 1995, cap. 3.
6. Rodrigues, J. C. V.; Kitajima, E. W.; Childers, C. C.; Chagas, C. M.; Exp. Appl. Acarol. 2003, 30, 161.

7. Childers, C. C.; Rodrigues, J. C. V.; Kitajima, E. W.; Derrick, K. S.; Rivera, C.; Welbourn, W. C.; Man. Int. Plagas 2001, 60, 76.

8. Bastianel, M.; Novelli, V.; Kitajima, E. W.; Kubo, J.; Bassanezi, R. B.; Machado, M. A.; Freitas-Astua, J.; Plant Dis. 2010, 94, 284.

9. Omoto, C.; Pestic. Sci. 1998, 52, 189.

10. Omoto, C.; Alves, E. B.; Ribeiro, P. C.; An. Soc. Entomol. Brasil 2000, $29,757$.

11. Campos, F. J.; Omoto, C.; Exp. Appl. Acarol. 2002, 26, 243.

12. Franco, C. R.; Casarin, N. F. B.; Domingues, F. A.; Omoto, C.; Neotrop. Entomol. 2007, 36, 565

13. Semir, J.; Doctoral Thesis, State University of Campinas, Brazil, 1991.

14. Sousa, O. V.; Silvério, M. S.; Del-Vechio-Vieira, G.; Matheus, F. C.; Yamamoto, C. H.; Alves, M. S.; J. Pharm. Pharmacol. 2008, 60, 771.

15. Silvério, M. S.; Sousa, O. V.; Del-Vechio-Vieira, G.; Miranda, M. A.; Matheus, F. C.; Kaplan, M. A. C.; Rev. Bras. Farmacog. 2008, 18, 430.

16. Keles, L. C.; Melo, N. I.; Aguiar, G. P.; Wakabayashi, K. A. L.; Carva1ho, C. E.; Cunha, W. R.; Crotti, A. E. M.; Lopes, J. L. C.; Lopes, N. P.; Quim. Nova 2010, 33, 2245.

17. Vichnewski, W.; Lopes, J. N. C.; Santos, F. D.; Herz, W.; Phytochemistry 1976, 15, 1775 .

18. Vichnewski, W.; Lins, A. P.; Herz, W.; Muraris, R.; Phytochemistry 1980, 19, 685

19. Bohlmann, F.; Zdero, C.; King, R. M.; Robinson, H.; Phytochemistry 1980, 19, 2663.

20. Bohlmann, F.; Zdero, C.; King, R. M.; Robinson, H.; Phytochemistry 1980, 19, 2669.

21. Bohlmann, F.; Muller, L.; King, R. M.; Robinson, H.; Phytochemistry 1981, 20, 1149.

22. Adams, R. P.; Identification oil components by gas chromatography/ mass spectrometry, Allured Publishing Corporation: Carol Stream, 1995.

23. Chiavegato, L. G.; Pesq. Agropec. Bras. 1986, 21, 813.

24. Nakano, O.; Sanches, G. A.; Ishida, A. K.; Laranja 1987, 8, 19.

25. Aslan, I.; Ozbek, H.; Calmasur, O.; Sahin, F.; Genn. Ind. Crops Prod. 2004, 19, 167.

26. Winer, B. J.; Brown, D. R.; Michels, K. M.; Statistical principles in experimental design, McGraw-Hill: New York, 1991.

27. SAS Institute; Sas/stat user's guide, version 8.1, SAS Institute, Cary: NC, 2001

28. Vichnewski, W.; Sarti, S. J.; Gilbert, B.; Herz, W.; Phytochemistry 1976, $15,191$.

29. Lopes, N. P.; Kato, M. J.; Yoshida, M.; Andrade, E. H. A.; Maia, J. G. S.; Phytochemistry 1997, 46, 689.

30. Vichnewski, W.; Takahashi, A. M.; Nasi, A. M. T. T.; Gonçalves, D. C. R.; Dias, D. A.; Lopes, J. N. C.; Goedken, V. L.; Gutiérrez, A. B.; Herz, W.; Phytochemistry 1999, 28, 1441.

31. Gobbo-Neto, L.; Lopes, N. P.; Quim. Nova 2007, 30, 374.

32. Pontes, W. J. T.; Oliveira, J. C. S.; Câmara, C. A. G.; Gondim-Júnior, M. G. C.; Oliveira, J. V.; Schwartz, M. O. E.; Quim. Nova 2007, 30, 838.

33. Baldin, E. L. L.; Pogetto, M. H. F. A. D.; Pavarini, D. P.; Lopes, N. P.; Lopes, J. L. C.; Bol. San. Veg. Plagas 2010, 36, 125.

34. Ferraz, A. D. F.; Balbino, J. M.; Zini, C. A.; Ribeiro, V. L. S.; Bordignon, S. A. L.; von Poser, G.; Parasitol. Res. 2010, 107, 243.

35. Pontes, W. J. T.; Silva, J. M. O.; Câmara, C. A. G.; Gondim-Júnior, M. G. C.; Oliveira, J. V.; Schwartz, M. O.; J. Essent. Oil Res. 2010, 22, 279.

36. Pontes, W. J. T.; Master Thesis, Federal Rural University of Pernambuco, Brazil, 2006. 